\title{
The Historical Background of the Trojan War.
}

By John L. Myres and K. T. Frost.

\section{Rameses III. and the Sea-Raiders.}

To give complete and accurate account of events in the Levant during the twelfth and thirteenth centuries B. C. is one of the most difficult tasks presented by ancient history. It is also one of the most fascinating; for it must include not only a summary of what is known of the peoples of Asia Minor, Syria and Egypt, but also a survey of the Mycenean Age, and the Late Minoan "Sea-Raiders". It is moreover the historical background of the Trojan War. It was a time of great unrest, of fierce invasions and national migrations, whose effects lasted long.

At the turn of the century, in 1200 B. C. these are the main lines of the picture. From the Adriatic Sea to the Persian Gulf a large proportion of cities and tribes were independent of any great overlord. Knossos had been overthrown for some two centuries and although partly reinhabited it no longer ruled the waves, and the Mediterranean was swept by the Late Minoan sea-rovers. Egypt was powerless abroad and decadent at home. Babylon was just driving out the Kassites who had ruled for some centuries, and as yet the new native dynasty had little influence outside ${ }^{1}$ ). Assyria, whose power had greatly declined since the death of Tukulti-Ninib some forty years earlier, was beginning to reassert herself but was still fully occupied in guarding her own frontiers. The empire of the Hittites was being finally overthrown by a fierce invasion of the Muski Phrygians who had crossed from Europe and were devastating Asia Minor. Further trouble was brewing in the North and pressure was felt from the Danube. The fortunes of all the great powers were at a low ebb: wars were frequent and records are scanty. Egypt alone gives us fragments of contemporary official narrative: particularly interesting in substance, it directly concerns the Homeric peoples, Achaeans, Danaans, Teukrians and the like, at the time of the traditional date of the Trojan

1) On the current reckoning; though a later date is suggested (seo Lehmann-Haupt, Zwei Hauptprobleme 1898 and Klio X, $476 \mathrm{ff}$.). 
War. In form, however, it is the narrative of the exploits of Rameses III. who more than any one man at that period decided the fate of the nations of the Levant.

Rameses III. ascended the throne in 1202 . It was a critical time. During the closing regions of the XIX. Dynasty, Egypt, though still rich, had lost most of its power and foreign prestige and was itself in a state bordering on anarchy. Military spirit had declined and there is evidence of an antimilitary spirit in the schools, probably fostered by the Priests deliberately to weaken the Crown, whose authority depended on the Army. The Priests of Amon were working for the temporal power, which they ultimately secured; and this temporal power was necessarily gained at the expense of the crown and foreign policy. But in the year 1203 Setnekht came to the throne. He was a military chief who had married a grand-daughter of Rameses II. His reign seems to have lasted no more than a year, but during it he reorganised the army and restored order to the country; and in this task he probably associated his son Rameses with himself.

Setnekht died in 1202 and Rameses became king. He continued his father's work vigorously. His first care was to reorganise the army. He organised chariotry, archers, and different kinds of infantry, and the co-operation of these in the field goes far to explain his victories: for he realised that an efficient field-force is a complex organism, that different arms of the service have their special duties, and that in action all arms and ranks must be dominated by the commander-in-chief, to ensure the. co-operation of all, and to turn an advantage to account. These principles sound very obvious and elementary, but they were seldom put into practice before the days of Philip and Alexander. In Homeric battles, which probably reflect the traditions of the Sea-Raiders against whom Rameses fought, the combatants seem to be launched at each other quite haphazard and engage in a general scrimmage; nor is there evidence that the Libyans had progressed any further than the Sea-Raiders, beyond this tribal system of fighting. Similar tactics, or absence of tactics, persist in the battles of the $\bar{\partial}^{\text {th }}$ century and recur even in the wars of the Diadochi. They are the natural mode of warfare among loosely organised levies, however brave and skilful their members may be individually. But organisation alone would have been of little use. The Sea-Raiders and their allies were formidable fighting men. Driven southwards apparently by pressure from the farther North, they had in many cases brought their families and property with them; they had staked their all on victory: behind them was the desolation they had wrought; before them, the gold and corn of Egypt. No less determined was the advance of the Libyans, tough fighters, even against modern artillery, as French and 
Italians know. No purely native Egyptian army could stand against such enemies. The Egyptian is not, and never has been, a soldier by nature. Yet Egyptian troops can form a useful supplement to foreign troops in Egyptian service. Hence throughout history we find in successful Egyptian armies, a large proportion of auxiliaries European, Asiatic or Negro. Rameses III. understood this well.

He has two other reforms to his credit. The Egyptians excelled all other nations at that time in archery, and in chariotry, which took the place of the cavalry and mounted infantry among the early Mediterranean and Eastern peoples. Egyptian chariotry it should be noted resembled cavalry far more closely than did the Homeric chariot-fighting, since in Egyptian warfare we find the chariots on occasion charging in mass, whereas Homeric heroes usually dismount and fight on foot; their chariots are vehicles, not weapons. Yet the main weapon even of the Egyptian chariotry was the bow. The Egyptian foot-archers too were efficient: they used a long bow which they drew to the ear, not to the breast as was the custom of Homeric bowmen, and of most other nations till then. The bows were not as long and not nearly as strong as the English long-bow, but their light reed arrows had a considerable range and their archers were numerous and skilful. Moreover they wore defensive armour of quilted linen which seems to have afforded ample protection from the long-range missiles of the enemy. Thus the Egyptian army possessed the great initial advantage of being able to strike hard at an enemy before he could reply.

Wars, however, are not decided by missile warfare alone. Victory is won in the end by hand-to-hand fighting or the threat of it. But the Egyptian is the very opposite of a Berserker and has always had to rely on more virile nations to bear the brunt of battle. Nercenaries and allies have always been prominent in successful Egyptian armies. Just as victory depended at Omdurman on the British and Sudanese regiments, so we find that the heavy infantry of Rameses was mainly composed of foreigners. Chief of these were the Shardana, an over-sea people, probably from an Aegean coastland, some of whom seem to have joined the "People of the Sea" in the great attack on Egypt in the eighth year of Rameses. They had been employed in the foreign wars of the later XVIII dynasty, but not in those of the XIX, which represents a period of anti-foreign reaction. It is therefore some testimony to the political courage of Rameses III., as well as to his military insight, that he ventured to reinstate these corps.

Rameses' other innovation is his fleet. Egypt had made occasional use of "King's ships" in the Tell-el-Amarna period, to patrol the Syrian coast, and in the early part of the XVIII dynasty Queen Hatshepsut had 
organized a great seaborne expedition to Punt, along the Red Sea. But in the Syrian campaigns of Rameses II no fleets appear. Yet for a strong foreign policy, under the conditions of the next generation, a sea-going fleet was a necessity; and Merenptah's difficulties, in his Libyan war, had been greatly increased through the want of it. But a fleet is no natural product of Egypt, an almost timberless country, and devoid of ports. Seeing then that the fleet of Rameses III., as presented to us, is no mere coast-patrol but thoroughly at home on the sea which it was designed to dominate, it is reasonable to suppose that here too, as in the land army, he turned his enemies against one another, and made use of Sea-Raider crews, if not also of oversea vessels. Just so, we find Greek fleets at a later date in Egyptian and in Persian pay.

But fleet and army, native and foreign alike, were commanded and paid by Rameses. How he raised the necessary means we do not know, but it must have been a hard struggle with the Priests.

The first attack came in his fifth year. The Libyan tribes who had recovered from their defeat by Merenptah, made a determined attempt to overrun the Delta; and they were helped by Sea-Raiders. This attack Rameses decisively defeated, strengthening his political position by the victory while he gained experience for his army and fleet. Then in his eighth year came the struggle which makes the reign of Rameses III a landmark in Mediterranean history. A great league of tribes of Asia Minor, and with them Sea-Raiders, combined to invade Egypt by land and by sea. Their strength may be measured by the record of their advance. "Not one stood before their hands; from Kheta, Kode, Carchemish, Arvad, Alasa they were wasted. They set up a camp in one place in Amor. They desolated his people and his land like that which is not. They came with fire prepared before them, forward to Egypt. Their main support was Peleset, Thekel, Shekelesh, Denyen and Weshesh. These lands were united and they laid their hands upon the land as far as the Circle of the Earth. Their hearts were confident, full of their plans." 1 ) So runs the inscription of Rameses himself on the north wall of his temple at Medinet $\mathrm{Habu}^{2}$ ). None of these peoples occur in the invasion from the west, and only the Shekelesh are found earlier in a western connection. The Peleset or Pulosatu are generally recognised as Philistines, a people of Cretan traditions, eventually domiciled also in Palestine to which they give their name. Here they are said to be "in the midst of the sea". The Zakkaru seem to be the Teukroi, whose legends are localized from, the Troad to Crete and from the Attic to the Cyprian Salamis; "perhaps

1) Breasted, Ancient Records, Egypt IV pp. 38-39.

2) For further commentary see Petrie, A. History of Egypt Vol. III p. 151. 
we may see the name yet in Zakro at the eastern end of Crete."1) The Denyen (Danauna) and Weshesh are both described as sea-folk. The former seem to be the Danaoi of Rhodes and Argos. The Uasha have been connected with Oaxos in Crete, with Ixid at the south end of Rhodes, with Iasos, on the mainland of Caria, or all three. Whatever the precise identification of these peoples may be, it is clear that we have record of an alliance between the powers of the Levant in the phase of culture known as Late Minoan MI. We are reminded of the expeditions of Minos and the Argonauts, in the Greek tradition; of the alliance arranged at the suggestion of Odysseus between the suitors of Helen before her marriage with Menelaus; and of the leagues of Priam and Agamemnon.

The records of the land campaign have unfortunately disappeared; but as the Hittites are mentioned as having been overcome by the confederacy, we must infer that the invaders carne from beyond the Hittite countries. There seems indeed no room for doubt that about the year 1194 the Egean states, the Teukrians, and other peoples of western Asia Minor, were on friendly terms and were acting together, and that it was this combined host which advanced now against Egypt, conquering and plundering as it went. The attack of 'Muski' folk on Assyria, (within a few years of this date if the common reckoning is upheld) is part of the same morement ${ }^{2}$ ).

Rameses determined not to await attack in Egypt. So he fortified his base, blocked the river mouths to secure his communications, and marched north-eastward. The exact site of the encounter is anknown, somewhere north east of the Delta, or in Southern Palestine, not far from the coast. There the two fleets and armies met, and fought the earliest known of the Decisive Battles of the World. The records of the battle on land have perished. But there is no doubt as to the result. The Egytians were completely victorious; the Northern host was shattered, and the Egyptian army turned swiftly to the coast to help the fleet, for victory by sea over the vikings of that age was much less likely than victory by land. But the triumph of Rameses was complete. "I was armed, and trapped them like wild fowl" says the king, and in inscription and reliefs he shows how this was done. The Egyptian fleet moving rapidly, surprised the Sea-Raiders in a bay, and blocked its mouth, while the army lined the shore. From all sides a storm of arrows rained in, to which the sea kings could not reply; for among the Aegean peoples archery was in small repute. Even Odysseus leaves his famous bow behind when he goes to the war, and Paris and Teukros counted for little beside Hector and Ajax. When the archers had done their work, the ships grappled.

1) Petrie l.c.

- 2) Annals of the kings of Assyria i. p. 35. (Cylinder of Tiglath-pileser I.) 
"They were dragged, overturned and laid low upon the beach; slain, and made heaps, from stern to bow of their galleys 1 )." The Confederacy was shattered and the survivors were made prisoners. Great numbers were taken to Egypt as slaves, or planted as colonists. Others were settled on the Syrian coast. They were probably intended as a sort of buffer-state against other invasions; they have given their name to Palestine, and are familiar to us as the Philistines of the Bible.

Rameses returned to Egypt laden with plunder, but he had still one more campaign to fight, for the Libyans made another determined effort to conquer the Delta. But in the 11 eleventh year of his reign he routed them completely and finally, and until after the twenty-sixth Dynasty Egypt had no further fear for the western frontier.

His last years were clouded by conspiracy and palace intrigues, the chief of which is recorded in the "Judicial Papyrus" of Turin. The conspirators were detected and "died of themselves". Then, about 1170, Rameses III died and was buried iu his rock-cut tomb in the Valley of the Tombs of the Kings. The danger and difficulties he had to contend with from within may be judged from the anarchy and civil war which distracted the country before his father's short reign of one year, and from the immediate resumption. of authority by the priests as soon as he was dead. The dangers from without have already been considerod. Far greater than any that had threatened Egyt since the days of the Hyksos, they were also more thoroughly overcome. If ever a man can be said to have changed the course of history, it was Rameses III, since the organisation which made victory possible was his work, no less than the leadership in battle. Had the Sea-Raiders attacked Egypt ten years earlier they would probably have found it an easy prey, and could have settled themselves unchecked throughout Palestine and Lower Egypt. The Late Minoan world, enriched and consolidated by their aggressions, might have withstood or at least diverted the Dorian Invasion.

But for the victory of Rameses there might have been no siege of Troy by the Achaeans. There might also have been no siege of Jericho by Joshua. For it seems to have been about this time that the Israelite tribes completed their wanderings and while the most powerful of them

1) Breasted op. cit. p. 39 (2nd Pylon.) The rest of Rameses' reign was peaceful, and was devoted, to developing the country. The country was well policed and seems to have enjoyed greater prosperity than at any time since the XVIII. Dynasty. That the priests had their reward is shown by enormous royal grants and gitts to temples, details of which are chronicled in the. Harris papyrus. The monuments of Rameses III are almost entirely confined to Tellel-Jahudiyeh and Thebes; and this with his own intention to imitate his most conspicous namesake, is probably the reason why he has usually been considered only a poor reflection of Rameses II. 
established themselves on the richer lands east of Jordan, the remainder were waiting for an opportunity to invade Canaan. This opportunity came when Rameses III broke the power of the Northern Invaders, and then withdrew and left the land exhausted. The poverty of the country is shown by the record of Israelite spoil, yet even so their conquest was only gradual: Jerusalem and Gezer retained their independence till the period of monarchy, and the land was not wholly subdued till the time of the Maccabees. With Philistine and Teukrian Land-Raiders in triumphant occupation it is difficult to believe that the Israelites could have won foothold at all.

The victory of Rameses III deserves therefore more attention than is usually given to it. It decided the fate of Egypt; it also affected profoundly the history of both the Jews and of the Greeks. It is the purpose of this essay to determine more precisely than has been attempted hitherto the relation in which it stands to the latter.

\section{The Greek Date for the Trojan War. Eusebius' date for the war.}

Eusebius thought that Troy fell in A. A. 835, that is to say, 405 years before the first Olympiad: in B. C. 1181. The war had begun in A. A. $826(=$ B. C. 1190). His collateral tables suggest that his evidence for this was mainly, if not wholly, genealogical. He had for this period two royal lines; a sequence of Kings of Attica, wherein Menestheus died on his way home from the war, and was succeeded by Demophon; and a sequence of Kings of Sikyon. He or his authorities certainly had also Achaean pedigrees which put the destruction of the Achaean kingdoms by the Heracleids in the second generation after that of Agamemnon and Menelaus; and from the coming of the Heracleids to historic times there ran pedigrees, both Dorian, like those of the kings of Sparta and Argos, and Ionian, like those of Hecataeus and the Peisistratidae. He has also genealogical dates on the Trojan side, for he puts the accession of Priam in 1237 (1235 Jerome); just a generation, that is, before the accession of Agamemnon, which Eratosthenes had reckoned at 1200. These concurrent data were enough to give a general notion of the date of the Trojan War, and to permit him or his authorities to proceed to refinements such as were suggested by the accident of Menestheus' death in the very year of the Return.

His Egyptian synchronism.

Eusebius gives also a sequence of Assyrian kings, so that Troy fell in the reign of Tautames, and probably in his $24^{\text {th }}$ year, for his accession is in A. A. 811'); and a sequence of Kings of Egypt. Thuoris, whom he

1) Tautames sub quo Ilium captum est. Arm. Sub Tautamo rege Assyriorum Troia capta est. Jerome. 
identified with Homer's Polybus, began to reign in A. A. 829, reigned seven years and consequently died in 836 . There is evidently a very tight fit of the chronology here; for it is only by supposing that Menelaus was carried directly from the Troad to Egypt, that his arrival there can be made to fall within the reign of Thuoris at all ${ }^{1}$ ). In any case the war began in the reign of his predecessor. Eusebius is of course using and summarizing older chronologies, and in outline we know how these treated the matter.

His sources: Eratosthenes.

Eratosthenes, working, so far as we can tell, on Greek genealogical materials only, reckoned 407 years from the Fall of Troy to the First Olympiad, and closed the Trojan War in $1183^{2}$ ). The war therefore broke out, for him, in 1193; the accession of Agamemnon was in 1200; the Argonautic Expedition in 1225, and the Coming of Pelops in 1283, just a century before the triumph of his grandson. We are probably justified in supposing that he reckoned here, as usual, three generations to a century, unless he had materials for a closer approximation; and there is no evidence that he made any attempt to compare these genealogical dates with any Egyptian reckoning. Apollodorus seems to have taken over the reckoning of Eratosthenes without change ${ }^{3}$ ).

\section{Callimachus.}

Callimachus agreed with Eratosthenes as to the length of the war, and the intervals which separated it from the Return of the Heracleidae and other events down the Olympiad of Iphitus; but below this point he took another side in the problem of Olympic chronology, and put his dates all lower down by 56 years. Consequently he was led to put the Fall of Troy in 1127 instead of 1183 . But his method, and probably also his materials for determining the earlier intervals, were the same as those of Eratosthenes. There is no reason to believe that he was influenced by any Egyptian evidence, or by the desire to conform to any tradition about the point in Egyptian history at which Menelaus visited Egypt after the war.

The other Alexandrian chronologers, in spite of minor discrepancies, agree on the whole with Callimachus rather than with Eratosthenes ${ }^{4}$ ), but the reason for this, as for Callimachus' own calculation, is a difference of opinion as to various later dates; not a difference of method or of materials for determining dates in general before $1000 \mathrm{~B}$. C.

1) Syncellus. 136. 13; and 320. 5 .

2) Clem. Alex. Strom. 1. 336.

3) Clinton. Fasti Hellenici I p. 125.

4) Clinton. Fasti Hellenici III p. vii. 


\section{Real Agreement.}

There is good reason for this unanimity. All alike, as K. O. Müller suggested long ago ${ }^{1}$ ), used the same body of evidence, accumulated by the logographers and summarized already by Thucydides to exactly the same effect as by the Alexandrians. And there is no reason to believe that the logographers themselves had any clear notion about the course of Egyptian history: least of all about the occasion of Menelaus' visit. Herodotus, for example, makes the Homeric Proteus into a king of Egypt, and places him after the 'blind' king Phero, and before Rampsinitus, whereas Thuoris comes several reigns later than Rampsinitus. That is to say, Herodotus' date for the Trojan War was appreciably earlier than that of Eratosthenes').

The Greek date for the war is independent of Egyptian evidence.

From all this, we may conclude that the Greek dates for the Trojan War were calculated independently of Egyptian chronology, and that the various attempts to identify the Homeric Thos and Polybos with Egyptian kings were obtained by collating the accepted Greek dates for the Trojan War with Egyptian chronologies constructed quite independently, and also quite inaccurately, as we now know from the Egyptologists. Herodotus, for example, as wo have seen, puts Proteus later than Sesostris and a blind king Phero, but earlier than Rampsinitus and another blind king Asychis; that is, somewhere between the Asiatic conquests of Dynasty XVIII, and the reigns of Rameses III and the other blind king Anysis, in whose days eame the Ethiopian invasion of Sabako. Manetho, whose Egyptian dates range higher, had to put the War later, and assigned it to the reign of Thuoris towards the close of his Dynasty XIX. Eusebius follows Manetho, putting the Fall of Troy close to the end of the reign of Thuoris the last king of Dynasty XIX.

Pliny alone speaks of Rhameses quo regnante Ilium captum est ${ }^{3}$ ).

We are therefore free to make a fresh collation of Greek and Egyptian chronologies without fear that we may be comparing only bad Egyptian evidence with good.

1) Die Dorier II p. 482. The conclusion of Mr. Chadwick (Heroic Age, Cambridge 1912, p. 183) that "the calculations of scholars of the Alexandrian age, or even earlier times, are not te be interpreted as evidence of tradition" may be accepted without prejudice to his own assumption that we have enough evidence of tradition, apart from the "calculations of scholars" to enable us to estimate, in generations, the interval between Homeric and Hellenic times. Mr. Chadwick brings the Homeric age down "at least to the close of the eleventh century" (p. 153), and regards this date as "corroborated to a considerable extent by the results of archaeological investigation" (p. 192). But his argument does not seem to us to be conclusive against the higher dates which we suggest here.

2) Clinton, Fasti Hellenici I 133 n. suggests 1263. - 3) N. H. XXXVI. 5.64. 


\section{Homeric and pre-Homeric Synchronisms.}

For this purpose, we have four sources of evidence: Egyptian documentary history, Greek genealogical folkmemory, Minoan archaeology, and such unassigned episodes as we may be able to bring into place in a confirmatory way.

A. Egyptian History from contemporary Documents.

Crucial dates, selected from the well-established history of Egypt, are as follows ${ }^{1}$ ):

XVIII Dynasty. Amenhotep III reigned from 1414 to 1379 . It was in his time that the first oversea peoples attacked Egypt; it was also he who was the first to enrol some of the Shardana, as mercenaries, to keep out the others. Amenhotep IV, the heretic king Akhenaten, reigned from 1383 to 1365 , sharing the throne with his father till the end of his fifth year, and changing his name and ereed in his sixth. He too had mercenaries from oversea. Hor-em-heb reigned from 1324-1320, a short phase of sole power, following probably on a long period of administrative regency, during the chaos in which things had been left by Akhenaten, in whose reign he was already "great general". With his death or deposition (for his fate is obscure) ends Dynasty XVIII.

XIX Dynasty. The two years of Rameses $I$ and the long reigns of Seti I and Rameses I run as follows: $1320-1318-1300-1235$. The indecisive battle of Kadesh, which reveals Egypt face to face with an equivalent Hittite antagonist in Syria was fought in 1295 , the $4^{\text {th }}$ year of Rameses II. In this battle some Dardanui or Derdeny folk fought on the Hittite side, together with Luka and other peoples whose names have an Anatolian look. The great treaty with the Hittites was concluded in 1279, Rameses' $21^{\text {st }}$ year. Merenptah reigned from about $1235-1225$. The chief event which concerns us in his reign is a Libyan invasion in the fifth year, probably 1230, in which numerous oversea peoples took part, including apparently some Achaeans. Then, after a few years of confusion, Dynasty XIX ends.

Dynasty XX begins about 1203 with Setnekht and the remarkable figure of Rameses III, portrayed in greater detail in the first section of this essay. Few dates in Egyptian history are better authenticated than that of his accession: and consequently, for all events dated by his regnal years, we are on sure ground. In his fifth year, 1197, comes a great raid of the Libyans and their allies; and in the eighth year, 1194, a confederate attack from Syria, partly of sea-peoples in ships, partly of landsmen migrating with their families, waggons and cattle. The Kheta are among them, but are no longer dominant. Then in the eleventh

1) Petrie, Hist. Eg. III 247. 
year, 1191, the Libyans attacked, and were repulsed again. This made Rameses secure, and the rest of the records of his reign deal mainly with internal administration.

\section{The Trojan War and Rameses III.}

Now it is certainly a remarkable coincidence that the Trojan War, as dated by Eratosthenes, broke out in the year following the great Confederate Raid, as dated by contemporary records of the eighth year of Rameses: particularly when we remember another coincidence just before, namely that on the journey when he carried off Helen, Paris had already traversed the Levant and carried off slaves from Sidon ${ }^{1}$ ); and that three years before the Confederate Raid the Libyans, of whom the Achaeans had apparently been allies in their former raid about 1230, were renewing their attacks on Egypt from the West. We do not know that any Achaeans took part in the Libyan Raid of 1197; but if they did, this would give an occasion for such an absence of Menelaus from Sparta as gave Paris his opportunity; and also for such a raid on the Coasts of the Levant, as is ascribed to Paris in Homer.

The Argonauts and Merenptah's Libyan Raid.

It becomes, however, something more than a coincidence, when we find that the earlier Sea-Raid in Merenptah's reign, about 1230, falls in the middle of the generation of the Argonauts, whose voyage marks a similar combined effort to enlarge the Egean horizon.

The Phrygian Conquest and Rameses II.

Still more striking is the correspondence between tradition and history, when we look back into the second generation before the War. On the one hand, some large political cause is required to account for the sudden change of policy which is expressed in the Treaty of 1279 between Rameses II and the Hittites. For nearly two centuries the Hittite power had been the principal foreign enemy of Egypt; and for a generation there had been almost constant war on their common frontier in Syria. Only some new danger, some common enemy, can account fully for the sudden friendship between the two peoples. Now without pressing the suggestion that the Dardanui who helped the Hittites at Kadesh in 1295 may have been Dardanians from the North West of Asia Minor, we have the quite independent Greek belief that somewhere about 1270 Laomedon founded Troy, and formed oversea connections, and also that in the youth of King Priam, who is very old indeed in the tenth year of the Trojan

1) The date of the Rape of Helen was however disputed in antiquity; Thrasyllus for example (frag. 3) put it as long as ten years before the outbreak of the War.

K 1 i o, Beitrage zur alten Geschichte XIV 4 
War, there had been a great Phrygian army operating on the Sangarius. If the Amazons represent an incursion of wild folk from the East, (as Dr. Leaf among others believes) ${ }^{1}$ ), they may be presumed to have done considerable damage in the Hittite country before they reached the Sangarius valley. If, as we are inclined to think, the Phrygians are presented by Homer as the aggressors, we may have in their Sangarius campaign the realization of what the Hittite king feared when he insured himself against Egypt in 1279.

Synchronism of genealogical data with the Fall of Knossos.

We have next to take into account genealogical indications of a crisis in the Egean, dated about 1400, and corresponding in its effects with the known effects of the Fall of Knossos about that time; and when we have done this, we shall be confirmed in the impression that the genealogical framework in which these scattered data are preserved, is not altogether devoid of historical value.

It is now certain from the Cretan archaeological evidence, that the Fall of the Palace of Knossos, the obliteration of the peculiarly Cretan phase of culture known as Late Minoan II, and the substitution of the mainly continental or 'Mycenaean' culture known as Late Minoan III, may be assigned to the latter part of the XVIII Dynasty, and most probably to the early part of the reign of Amenhotep III (1415-1380 B. C.). The sequence of events is briefly as follows. Main symptoms of the Minoan decline, which becomes rapid with the transition from L. M. II (the Palace Style) to L. M. III, are (1) the collapse of the centralized Knossian regime in Crete, about 1400: (2) the revival of the smaller Cretan towns, and eventual occupation of Knossos itself by people whose culture propagates that of the Mainland sites contemporary with the Knossian Palace--such as Mycenae and Rhodes; (3) the prosperity of Rhodes, which is to be connected with the rapid colonization of Cyprus, already begun before 1400 , and not seriously damaged till after the reign of Rameses III (1150); (4) consequent upon this, in turn, more copious intercourse between Egypt and the non-Cretan sites, Cyprus, Rhodes, and Mycenae. As this intercourse dates at least from Amenhotep III's reign, and lasts into Ramessid time, its synchronism with the period of Knossian depression is probably some measure of the degree to which Knossos had stood in the way of the northern cities in the earlier stages of their growth.

Egyptian symptoms of the Fall of Knossos.

Of the convulsion in the Egean about the time of Amenhotep III it is possible to trace symptoms both in Egyptian history and in Greek

1) W. Leaf, Troy, a Study in Homeric Geography, 1912, p. 292-3. 
tradition. It is probably not wholly accident that it is in the reign of this king, and of his successor Amenhotep IV (Akhenaten), that we begin to find oversea folk not merely visiting Egypt, but employed as mercenaries in the Egyptian service: exactly the result which we should expect, if on the one hand Egean peoples were beginning a new aggressive movement, such as colonized Cyprus at this time; and if, on the other, these peoples were divided among themselves, and also some of them were dispossessed and ready to serve against their rivals as the mercenaries of a foreign power.

\section{Achaean Genealogies.}

Now in Greek tradition, as we have seen, the generation of the Trojan War has its floruit about 1200 . The generation next above therefore has its floruit about 1235. To this belong Priam, Nestor, Peleus, Atreus, Jason (for his son Evenus is king in Lemnos in Homer) and Deukalion (father of Idomeneus and brother of Ariadne), together with Theseus in Attica, Eteokles in Thebes and others besides. For the two last, of course, we must allow a margin of half a generation, on account of the frequent misfit between Achaean and non-Achaean genealogies: within this margin of some fifteen years, however, we are probably on safe ground. It follows that the generation of Minos (father of Deukalion), Laomedon (father of Priam), Pelops (father of Atreus), and Oedipus (father of Eteokles), stands about 1266; and the generation of Laius (father of Oedipus), and of Tantalus (father of Pelops) about 1300.

\section{Pre-Achaean Genealogies.}

Here Pelopid genealogy fails us, for Tantalus lies outside Homeric history: and in Crete, even in the generation below, Minos II, father of Deukalion, has no human predecessor: here therefore there was a breach of some kind. But the Theban pedigree persists, and it goes up as follows: Laius 1300-Hippodamas 1333-Labdakos 1366-Kadmos 1400. It was therefore at a date corresponding with the middle of the reign of Amenhotep III that Greek tradition placed the famous opening up of Central Greece to knowledge of the Levant and its wonders ${ }^{1}$ ). For Crete, too, this genealogy is of importance, for in the Nekuia (which, as Ridgeway suggested ${ }^{2}$ ), is concerned with pre-Achaean memories) Europa, sister of Kadmos, is also daughter of a king of Crete; and her son, who has no human father, is Minos I. It is no great stretch of probability to suppose that here too the fatherless king was the first of a new line: if

1) H. R. Hall in his Ancient history of the Near East (London 1913), p. 60 n. has recently taken a different view, but has not stated his case fully enough to be discussed here.

2) Early Age of Greece I, (London 1902), p. 639-41. 
he was also the son of Europa, and nephew of the man who opened up Boeotia, his personality may well mark the establishment of a new line

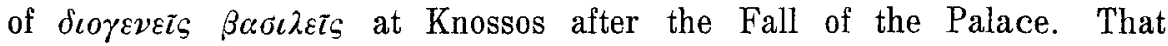
memories of this change of dynasty should be confused later with tales of the Achaean occupation about a century after, is natural enough; especially if the kingship was a priesthood, with a divine 'throne-name', Minos as seems to be probable. The opening chapters of Plutarch's Theseus suggest that such a conflation happened; and the bearings of all this on the early history of Attica, and on the circumstances of the

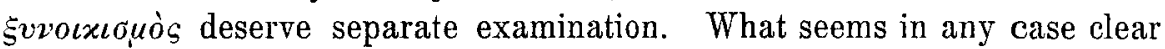
is, first, that the coming of the Achaeans, two generations before the Trojan War, can have had nothing at all to do with the Fall of Knossos, and was separated from it by four generations of men: secondly, that Greek tradition nevertheless preserves some record of a previous breach of continuity among the great families of the Egean, at a point which corresponds very closely with the Knossian debâcle.

The Trojan equivalents of these Genealogies.

Returning now to the political situation which entailed a Trojan War, the Homeric evidence is clear, and fairly full. Two generations before the war, the Greek peninsula, with many of the islands, was over-run

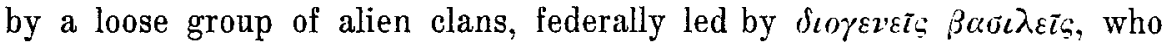
are the Achaean aristocracy. The family of their "king of kings" was in some sense Phrygian: but this need not mean more than that this family was of the same stock as the Phrygians who, as the Homeric story shows, were pushing into Hellespontine Phrygia in the same generation as Pelops and his followers entered Greece. Laomedon, in the same way is not only the founder of Troy-town, but the first human personage among its kings: all before him,-Ilos, Tros, Erichthonius, Dardanus, and Teucrus-are eponymous, and to date them there is only the late evidence of Tzetzes, that Teucrus who himself came from Crete, overlaps the generation of Phoenix King of Crete and his daughter Europa, and that his younger contemporary, Dardanus, who is Zeus-born and an immigrant from Samothrace, belongs to the generation of Kadmos and Europa.

\section{A Political History of the Troad.}

We obtain therefore this outline of the history of the Troad in the fourteenth and thirteenth centuries. First it was affected by the diaspora which followed the Fall of Knossos, and received at about that stage, perhaps in some sense "from Crete", the Teukrian population which links it so perplexingly with Teucrian Salamis off Attica, Teucrian Salamis in Cyprus (which must be supposed on purely archaeological evidence to 
have received its Late Minoan colony about 1400), and so, with the searaiding Tikkara and the East-Cretan Zakro ${ }^{1}$ ). Then it suffered conquest by successive Thraco-Phrygian tribes represented in Homeric legend by their eponymous heroes Dardanus, Tros and llos. Among these Dardanus is Zeus-born, an immigrant, and a contemporary of his predecessor Teucrus, who does not appear in Homer at all: and Erichthonius was remembered as the introducer of the divine horses of the North. Then, about 1270, the Troad fell under the Phrygian rule of Laomedon, who may well have built the Sixth Town of Hissarlik, seeing that this powerful fortress goes back to L. M. III, but not to the beginning of it. Laomedon in Homer ${ }^{2}$ ) is an austere man, ${ }_{\varepsilon}^{\prime \prime} \kappa \pi \alpha \gamma \lambda \sigma o s$, with a wide oversea connection among the distant islands and presumably a fleet ${ }^{3}$ ): a slave trade like that which Evenus still carried on in Lemnos during the Trojan War; and a predilection for the "cutting of ears" which seems endemic among rulers of the Dardanelles.

It was Laomedon's spoliation of famous and rich temples of Poseidon and Apollo that financed his fortification of the Dardanelles, and brought on him.the wrath of those older deities, (the horse-god of Erichthonius, and the local mouse-god, adopted by the older Tencrus) and the heavy hand of Herakles. It was in Laomedon's time, too, while Priam was still a young man, that the Phrygians fought their great battle with the Amazons on the banks of the Sangarius. Whether the Phrygians were the aggressors (as was suggested in $J . H . S . \mathrm{XXVI}$ ), or the Amazons, (as Dr. Leaf thinks in his Troy) the conclusion is not affected that the Phrygians were by this time in occupation of more than Hellespontine Phrygia, and had forces which Homer makes Priam compare with the whole league of Agamemnou. This is one of Priam's early memories, and Priam was very old at the time of the Trojan War. The reign of Laomedon ${ }^{4}$, then, cannot have been believed by Greek folkmemory to have begun much later than 1270; and this squares with the Greek belief that Trojan prosperity received some check at the hands of Heracles, at the end of Laomedon's reign. The date of this incident has to be more vaguely stated, because the Heracleid genealogy is one of those nonAchaean ones, already noted, which do not reckon their generations from the "Achaean Era"; so that Heracles, like Theseus and Eteocles, stands on a sort of "half-landing“ or mezzanine-floor between two Achaean generations. by Hall.

1) This identification was suggested by Flinders Petrie, and is supported

2) II. XXI 446.

3) Dr. Leaf thinks otherwise, but does not take account in his Troy of the considerations submitted here. Heraclea.

4) See Tzetz. Lyc. 522. on the sin of Laomedon, quoting Herodorus of 
We note, for example, in Homer, how Agamemnon "remembered" the visit of Tydeas and Polyneices, but "did not see them": he had been just led upstairs to his nurse, when the visitors arrived ${ }^{1}$ ).

Then, in the generation of Laomedon's son, Priam, come events which lead to a Trojan War: and we are now in a position to project this war upon its background in the history of the Levant.

\section{The Historical Causes of the Trojan War.}

The synchronisms which have been noted in the previous section suggest very strongly that the Greek date for the Trojan War is a historical date, and that the outbreak of that War stands in some real historical relation to the Great Raids. But whereas the Great Raids show us Sea Raiders and Land Raiders combining for aggressive action on the Palestinian coast, the Trojan War is the war of a maritime confederacy of the powers south and east of the Egean, from Rhodes and Kalymnos to Thessaly, against a league of the northern and eastern shores, which are continental, and are represented as acting on the defensive around a central land-fortress on the Dardanelles. Yet some of the most identifiable of the Sea Raiders bear names which refer them to these continental coasts. In Homeric story, in fact, the world of the Sea Raiders is divided against itself, only very shortly after the victory of Rameses over what seems to have been a very large and important part of its forces. Even the occasion of the quarrel has come down to us, little as this concerned the course or the issue of the war. In the absence of the King of Sparta a Trojan prince came, not as an enemy but as a friend and a guest, and stole his wife and his treasure: and as Helen was the heiress of the pre-Achaean dynasty, she was not only the consort, but the title-deed of Menelaus. War followed, so unanimously that later Greeks, who did not value their women so highly, were at a loss to account for it; pressed with such vigour and tenacity that it may well have had an economic cause as well as racial and political. Modern research and excavation tends to re-establish and confirm this belief. Dr. Leaf's recent book restates with full local knowledge the bearing of the tangible evidence of sites and remains, on Homeric statements about Troy and the War. Whatever the details and personalities may have been, we may accept as correct the general picture given by Homer of Troy, and of the cities of the Mycenean League. It is worth noting also that in Greek legend, Achaean Sea Raiders stand in a double position to the King of Egypt. When it is a question of telling a plausible "old soldier's tale", Odysseus has recourse to the Sea Raids of olden time: he has harried the lands

1) $12 . \mathrm{IV} 314-7$. 
about the Nile, been defeated by an Egyptian army, and then held in honourable detention, like the Shardana Mercenaries of Rameses III. The Taphians, in the same way, when Laertes still ruled in Ithaca, went slaveraiding, like Paris himself. But when it is a question of recent history, and of events subsequent to the Rape of Helen, Menelaus the Achaean is the friend, not the enemy, of the King of Egypt, and Helen is the friend of his Queen.

\section{V. „Rameses of the Fleet and the Cavalry".}

Two points remain, which fall now into their place in this chronological and historical framework. It has always been a difficulty, in the traditional account of the Trojan War, that there is no hint of naval opposition to the Achaean attack. Where was Priam's fleet? We know that Laomedon had had a large oversea trade, and though Troy had paid heavily for the sacrilege of Laomedon, Paris had been able to reach Sparta and Sidon without special remark. The answer seems to be given by the sequence of events which we have tried to reconstruct. The fleet of the enemies of Egypt in 1194 was Priam's fleet, either wholly or in part; and in its unexpected destruction by the new ${ }^{1}$ ) fleet of Rameses III, the Achaeans were given the occasion for a blow at the heart, which Priam was powerless to avert ${ }^{2}$ ).

The other point is closely connected with this one. Egypt as a rule had no sea-going fleet: and Rameses III expressly takes credit for his successfal obstruction of the mouths of the Nile, as well as for the naval victory which in fact made these barriers superfluous. Now one of the numerous kings whom Greek writers knew as Rameses is distin-

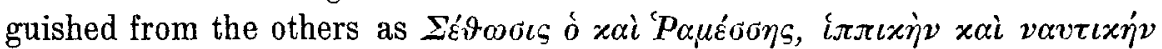
"z $\chi \omega \nu$ divaucv. The phrase is preserved by Josephus from Manetho ${ }^{3}$ ):

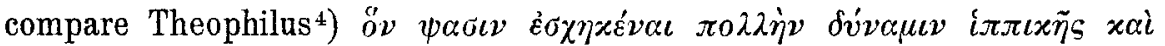

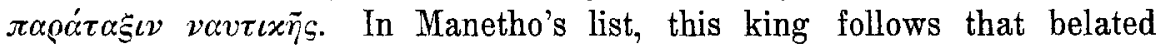
Amenophis who himself follows the great Ramessid group in the earlier half of Dynasty XIX. In spite therefore of an excusable confusion with the great pair of conquerors Seti I and Rameses II, a century before, this later Rameses must be identified with some king not earlier than Merenptah, (the belated Amenophis) and also not much later. The allusion to his fleet and his cavalry makes it clear that he is none other than

1) Not the first Egyptian fleet, but a reconstruction after the end of the XIX. Dynasty.

2) Dr. Leaf's hypothesis that the ruler of Troy could close the Hellespont without a fleet, by merely holding the watering places, takes insufficient account of the neighbouring islands, Lemnos, Imbros, Tenedos, which have precisely this function as watering places, and were out of Priam's control.

3) fr. 50. Müller. - 4) = Manetho fr. 51. Müller. 
Rameses III, the king who beat the Sea-Raiders on their own element, and also beat the Land Raiders on theirs. His alternative name $\Sigma \varepsilon^{\prime} q \sigma o c \varsigma$ very likely veils that of Setnekht, the short-lived father and co-regent of Rameses III.

This identification is supported further, in a rather remarkable way, by the remainder of Manetho's account of this king ${ }^{1}$ ). „This man left his brother Armais as governor of Egypt, and endowed him with all the rest of the royal authority; only he bade him not to put on the royal crown, or to do harm to the queen who was the mother of his children, and to keep away from the rest of the king's women. He himself made war upon Cyprus and Phoenicia and again on the Assyrians and Medes, and made them all his subjects, some with his spear, others without a battle, and for fear of his great power. And in much confidence at his successes, he went on even more boldly, conquering the cities and countries of the East. When some time had passed, Armais who was left in Egypt began to do freely all the opposite of what his brother had told him. For he laid hands on the queen, and used unsparingly the other royal women. And at the suggestion of his friends, he began to wear the crown, and rose against his brother. But the superintendent of

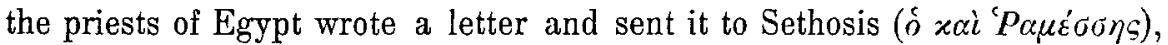
telling him all, and how his brother Armais had risen. So forthwith he returned to Pelusium, and secured his own kingdom. And the country was called after him Egypt; and he (Manetho) says that Sethosis was called Aegyptus, and Armais his brother, Danaos. Thus far Manetho." Josephus then goes on to reckon the date of the Exodus, on the assumption that Armais-Danaos is the man with the fifty daughters, who came to Argos long before the Trojan War. This detail alone is sufficient to show how far the Greek historians of Egypt were from realising the synchronism of Homeric with Nilotic dates, which this essay attempts to make good.

It does not take much study to discover in this story an allusion to a notorious episode of the reign of Rameses III, of which we have full details in the Rollin Papyrus and in the Judicial Papyrus of Turin. It was a conspiracy of the women in the harem, and involved some highly placed officials, including three members of the Special Commission which was appointed to investigate the case. The precise date is not known, but it can hardly have been earlier than the king's foreign campaigns, which all fall as we have seen, in the early part of his reign.

Two minor points may be noticed. The special injunction not to touch the royal women, though natural at any time, comes with especial force from Rameses III, in view of what we know not only of his personal

1) fr. 50. Müller, preserved by Josephus. 
tastes, but of the gossip and caricature to which they gave occasion in his life-time. No king of Egypt is so mercilessly satirized as he.

The other point is the title of the "superintendents of the priests". The relations of the Egyptian Crown with the Priesthood had been strained already - as at all period of energetic civil rule-under the earlier kings of the Eighteenth Dynasty: the heretical enthusiasm of Akhenaten provoked an open breach: and the enormous benefactions of the Ramessid Kings are a measure of the price of reconciliation. Rameses III himself takes credit in the same way for very rich gifts to the gods. But he was also a strong king, and did much to restore good government and particularly to repress extortion. No one is more likely to have needed a trustworthy "superintendent of the priests" then he; and this detail of the story is in close accord with the policy of his reign, and with the special circumstances which dictated it.

Returning now to Manetho's narrative, as summarized by Josephus (Fr. 52. Müller). To Rameses "of the fleet and the cavalry" follows another Rameses, who (like his predecessor Horus, the heretic Akhenaten) wished to "see the Gods" and cleansed the land of "lepers and other unclean persons". This for Josephus is the beginning of the Oppression, and leads to Osarsif and the Exodus. For us, it may well represent the internal reforms, and large concessions to priestly purism, which mark the later part of the long rule of Rameses III, and the increasing intolerance of the priests of Amon which characterizes the reigns of his successors.

Then follows a blundered list of kings, some of whom are Ramessids of the twentieth dynasty, others recopied from lists of the nineteenth Dynasty, Sethos, Rapsakes, Amenephthes, Rameses, Amenemnes ${ }^{1}$ ); and only then comes Manetho's Thuoris, "who in Homer is called Polybos, the husband of Alexandra, in whose time Ilion fell." So far is Manetho from realizing that the Rameses "of the fleet and the eavalry" is the Rameses of whom.Pliny says that in his time Troy was taken. (N. H. XXXVI, S. 64.)

Further proof that Manetho, when he wrote of this king, had no notion that he was dealing with a contemporary of the Trojan War, results

1) These repetitions of royal names in Manetho's lists have caused some perplexity. In view of the probability that (whatever other sources he may have had at hand) Manetho at least tried to use monumental evidence, it seems reasonable to suppose that he was sometimes led astray, like distinguished successors, by tinding, for example, a royal name of the Nineteenth Dynasty engraved upon a monument which on other grounds seemed to be work of the Twelfth er Eighteenth. Other evidence of the use of re-inscribed monuments, or of partially obliterated names, is the curious set of imperfect transcriptions

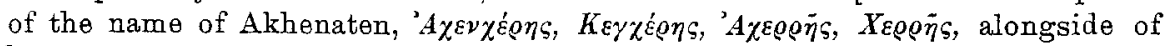
"Qoos who represents this king as co-regent with his father, in the years before his conversion to the cult of the Disc. 
from his identification of the king's brother "Aouais or "Equcĩos with Danaos the brother of Egyptus; for Danaos of the fifty daughters, though very likely their exploits are yet another echo of the Ramessid Harem-Conspiracy, belongs to a quite different period in Greek legend.

But what made Manetho identify Danaos with Armais the Egyptian? And what made Eusebius apply the identification with Danaos to this

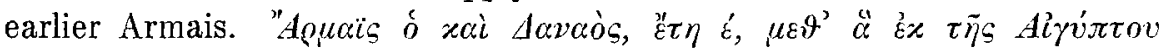

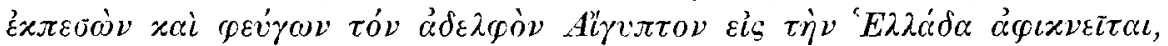

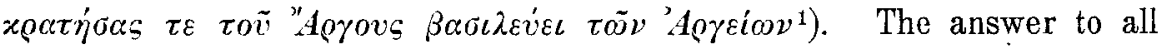
these questions seems to be one and the same. It should be noted that our knowledge of Egyptian history, as recorded by Greeks, becomes suddenly vague at the end of the XIX Dynasty; no list of Kings being at all given for the XX Dynasty. On the other hand, the most important reign of the XIX Dynasty, the long rule of Rameses II, is included twice over, once at the end of the XVIII Dynasty, and again in its proper place in the XIX, but later by some generations than the Rameses "who had the fleet and the cavalry". The cause of confusion seems to be the Ramessid character of both the XIX and the XX Dynasties: the successors of Horemheb have been included by Manetho in the XVIII, as well as (in greater detail in the XIX Dynasty; but when once the early kings of the XIX Dynasty, Seti I and Rameses II, had been confused (very naturally) with the founders of the XX Dynasty, Setnekht and Rameses III, the reduplicated XIX Dynasty list was mistaken for the Ramessid names which make up the XX Dynasty, and the latter dropped out altogether, leaving a blank space in Greek accounts of that dynasty ${ }^{2}$ ).

We have also seen already how the Kings of the Nineteenth Dynasty have paid the penalty of their frequent appropriation of Eighteenth Dynasty buildings by being mistaken by Manetho for Eighteenth Dynasty

1) Sync. $62 \mathrm{C}, 69 \mathrm{C}, 71 \mathrm{D}$.

2) It is perhaps worth noting that the King Remphis of Diodorus I, 62, who is the Rampsinitos of Herodotus II 144, is preceded by a King Keten (Kí $\tau v v$ ), whose name seems to represent that of Setnekht: and who is identified by Diodorus with Proteus the contemporary of Meneleus. Was this "first" king $\left(\pi \varrho \omega \tau \varepsilon v^{\prime} \omega \nu\right)$ who "changed his form" an echo of the change of Dynasty, and the one year's reign of Setnekht preceding the stable regime of Rameses III? "In view of the ancient translations of the names, it is tempting to connectEratosthenes'

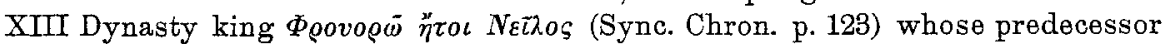

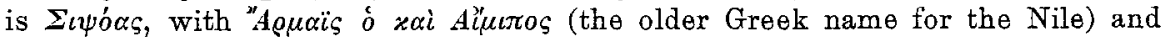

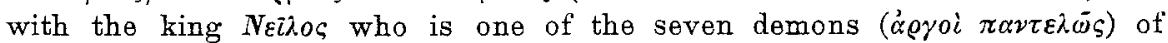
Remphis in Diodorus I, 63, and was dated by Dicaearchus (fr. 7 Müller) to 436 years before the First Olympiad (=1212 B. C.). Bunsen long ago supported that $\Sigma \iota \psi \alpha_{\alpha} \varsigma$ was really $\Sigma \iota \psi \vartheta \tilde{c} s$, Si-ptah, consort of Ta-usert whom Petrie (Hist.

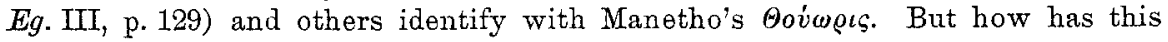
$\Phi$ @ovoe $\ddot{\omega}$ of Eratosthenes' wandered into the XIII Dynasty? 
kings. Now the actual predecessor of the first Rameses was a very remarkable personage, Horemheb, who rose to power as "great general" under Akhenaten, and eventually became king in fact about four years before the accession of Rameses I. He left no issue, apparently, and it is not certain that he was buried in the fine tomb which he prepared. Now we know that one of the public grievances in Akhenaten's time was the multiplication of foreign officials and foreign mercenaries about the court. We know also that when Horemheb had at last become king, he disappeared, for all his efficiency, within four years, and gave place to a new dynasty more typically nationalist and "Egyptian" than anything that Egypt had known since the first days of the Eighteenth, nearly three centuries before. Is it possible that Horemheb was in fact $\delta$ xai Savcós, „he who was also the Danaan“, a leader of Danauna, or other foreign mercenaries; and that the party-cry of the first Rameses o xai Al' $y v \pi \tau o s$ was "Egypt for the Egyptians"1). So much for the earlier Harmais.

On the other hand, the first contemporary record of Danaans, is as participators in the Great Raid, in the eighth year of Rameses III: and we know enough of this king's early years to detect a very vigorous clearance of alien folk, Syrian and other, from the frontier districts, such as underlies also the Manethonian account of the Exodus, if Manetho has been at all correctly quoted by Josephus. Setnekht's actual predecessor seems to have been a Syrian of some sort. Considering that Egean settlements in Palestine certainly go further back than this, and that a Danaan settlement lasted on there more than a century later, it seems not at all impossible that Danaan squatters within the Delta were expelled with the rest; and that this measure became confused in Greek tradition, on the one hand with the deposition of the earlier Armais, on the other with the Harem Conspiracy with which it was in fact contemporary. Oxford and Belfast.

1) It is perhaps worth noting, as a starting point for further work, that the reign of Horemheb falls close below 1325: contemporary that is, in Greek genealogy, with Hippodamus of Thebes, and in the Hellespont with Tros, and with that Phrygian overlord Adrastus who gave to Ilus the title deeds of Ilion. 